\title{
Estrogen receptor- $\alpha$ interaction with the CREB binding protein coactivator is regulated by the cellular environment
}

\author{
B M Jaber, R Mukopadhyay and C L Smith \\ Molecular and Cellular Biology, Baylor College of Medicine, One Baylor Plaza, Houston, Texas 77030, USA \\ (Requests for offprints should be addressed to C L Smith; Email: carolyns@bcm.tmc.edu)
}

\begin{abstract}
The p160 coactivators, steroid receptor coactivator-1 (SRC-1), transcriptional intermediary factor-2 (TIF2) and receptor-associated coactivator-3 (RAC3), as well as the coactivator/integrator CBP, mediate estrogen receptor- $\alpha(E R \alpha)$-dependent gene expression. Although these coactivators are widely expressed, ER $\alpha$ transcriptional activity is cell-type dependent. In this study, we investigated ER $\alpha$ interaction with p160 coactivators and CBP in HeLa and HepG2 cell lines. Basal and estradiol (E2)-dependent interactions between the ER $\alpha$ ligand-binding domain (LBD) and SRC-1, TIF2 or RAC3 were observed in HeLa and HepG2 cells. The extents of hormone-dependent interactions were similar and interactions between each of the p160 coactivators and the ER $\alpha$ LBD were not enhanced by 4-hydroxytamoxifen in either cell type. In contrast to the situation for p160 coactivators, E2-dependent interaction of the ER $\alpha$ LBD with CBP or p300 was detected in HeLa but not HepG2 cells by mammalian two-hybrid and coimmunoprecipitation assays, indicating that the cellular environment modulates $E R \alpha-C B P / p 300$ interaction. Furthermore, interactions between CBP and p160 coactivators are much more robust in HeLa than HepG2 cells suggesting that poor CBP-p160 interactions are insufficient to support ER $\alpha-C B P-p 160$ ternary complexes important for nuclear receptor-CBP interactions. Alterations in p160 coactivators or CBP expression between these two cell types did not account for differences in $\mathrm{ER} \alpha-\mathrm{p} 160-\mathrm{CBP}$ interactions. Taken together, these data revealed the influence of cellular environment on $\mathrm{ER} \alpha-\mathrm{CBP} / \mathrm{p} 300$ interactions, as well as CBP-p160 coactivator binding, and suggest that these differences may contribute to the cell specificity of ER $\alpha$-dependent gene expression.
\end{abstract}

Journal of Molecular Endocrinology (2004) 32, 307-323

\section{Introduction}

Estrogen receptor- $\alpha(\mathrm{ER} \alpha)$ is a ligand-regulated transcription factor, which plays an important role in the growth, development, proliferation and maintenance of reproductive and various other tissues. Based on sequence comparisons, the 595 amino acid length of human ER $\alpha$ is divided into 6 regions named A through $\mathrm{F}$ (reviewed in CarsonJurica et al. 1990, Green \& Chambon 1991, Tsai \& O’Malley 1994). The N-terminal A/B domain which contains a ligand-independent activation function (AF-1), exhibits little conservation among nuclear receptor superfamily members. The centrally located DNA binding domain (DBD), which is highly conserved across members of the receptor superfamily, corresponds to region $\mathrm{G}$ and enables the receptor to bind to estrogen response elements located in the regulatory regions of estrogenresponsive target genes. The $\mathrm{D}$ and $\mathrm{E}$ regions encode the hinge and ligand-binding domain (LBD), respectively, and are important for nuclear localization, receptor dimerization and transcriptional activity. The LBD is composed of 12 $\alpha$-helices arranged as a 3-layered antiparallel $\alpha$-helical sandwich which forms the hydrophobic pocket to which ligands bind (Brzozowski et al. 1997, Shiau et al. 1998). In addition to ligand binding, region $\mathrm{E}$ contains a second, liganddependent, activation function (AF-2). The function of the most $\mathrm{C}$-terminal domain, region $\mathrm{F}$, is not well understood, but appears to play a role in 
modulating antiestrogen activity (Montano et al. 1995, Nichols et al. 1998). The relative contribution of each activation function to $\mathrm{ER} \alpha$ transcriptional activity varies depending on the cell and promoter context in which receptor function is assessed (McDonnell et al. 1995, Tzukerman et al. 1994). However, in most contexts, AF-1 and AF-2 synergize to maximally induce $\mathrm{ER} \alpha$-dependent gene expression (Lees et al. 1989, McInerney et al. 1996, Tora et al. 1989).

Coactivators are required for efficient regulation of transcription by nuclear receptors (Glass \& Rosenfeld 2000, Robyr et al. 2000) and many ER-binding cofactors have been identified. These include members of the p160 steroid receptor coactivator (SRC) family of coactivators, SRC-1 [NCoA-1; (Onate et al. 1995)], transcriptional intermediary factor-2 [(TIF2) GRIP1/NCoA-2/ SRC-2; (Hong et al. 1996, Voegel et al. 1996)], and receptor-associated coactivator-3 [(RAC3) p/CIP/ ACTR/AIB1/TRAM-1/SRG-3; (Anzick et al. 1997, Chen et al. 1997, Li et al. 1997, Takeshita et al. 1997, Torchia et al. 1997)] as well as other coactivators such as E6-AP (Nawaz et al. 1999), CREB binding protein (CBP)/p300 (Kamei et al. 1996, Smith et al. 1996), DRIP205 (Burakov et al. 2000) and the p68/p72 RNA binding proteins (Endoh et al. 1999, Watanabe et al. 2001). Upon ligand binding, the ER undergoes a conformation change in its ligand binding domain which stabilizes a coactivator interaction site comprising a hydrophobic groove formed by residues in helices 3, 4, 5 and 12 (Beekman et al. 1993, Brzozowski et al. 1997, McDonnell et al. 1995, Shiau et al. 1998). Moreover, recruitment of pl60s to ER is dependent on the integrity of helix 12 (Mak et al. 1999). The p160 coactivators, through a highly conserved signature motif termed the nuclear receptor (NR) box which encompasses the core consensus sequence LXXLL (where $\mathrm{L}$ is leucine and $\mathrm{X}$ is any amino acid) are recruited to nuclear hormone receptors (Heery et al. 1997, McInerney et al. 1998). There are multiple NR boxes within CBP and SRC family coactivators, and the amino acid sequences surrounding the core LXXLL motifs play an important role in regulating receptor-coactivator interactions (Chang et al. 1999, McInerney et al. 1998). Recruitment of coactivators to $\mathrm{ER} \alpha$ enables the resulting complex to bridge the receptor to the general transcription machinery as well as remodel chromatin structure and thereby facilitate gene expression (Glass \& Rosenfeld 2000, Jacq et al. 1994, Kraus \& Kadonaga 1998).

It has been well established that ERs exert their effects in a cell- and tissue-specific manner (Katzenellenbogen et al. 1996). This has been attributed to differences in the relative strength of the AF-1 and AF-2 domains of ER $\alpha$ in various cell types which in turn are dependent on the cell-specific expression, activity or accessibility of cellular factors with which $\mathrm{ER} \alpha$ must interact to efficiently stimulate gene expression. These cellular factors could include other transcription factors (Porter et al. 1997, Webb et al. 1995), molecules that regulate $\mathrm{ER} \alpha$ interaction with DNA (Verrier et al. 1997, Zhang et al. 1999) and coregulatory proteins (e.g. coactivators and corepressors) (Glass \& Rosenfeld 2000, McKenna et al. 1999, Robyr et al. 2000). The interactions of pl60 coactivators and CBP with ER $\alpha$ have been studied extensively by in vitro approaches that have defined the regions of $\mathrm{ER} \alpha$ and coactivators critical for protein-protein interactions (Demarest et al. 2002, Heery et al. 1997, Henttu et al. 1997, Hong et al. 1996, Kalkhoven et al. 1998, Kamei et al. 1996, Mak et al. 1999, Norris et al. 1998, Torchia et al. 1997, Voegel et al. 1996). In comparison there are fewer studies of the in vivo interactions between $\mathrm{ER} \alpha$ and coactivators, although these support the general conclusion that $\mathrm{ER} \alpha$ binds to coactivators in an estrogendependent manner (Harnish et al. 2000, Llopis et al. 2000, Shang et al. 2000, Stenoien et al. 2000, 2001a, 2001b, Tikkanen et al. 2000). However, intracellular signaling pathways influence p160 coactivator and CBP/p300 activity (Font de Mora \& Brown 2000, Lopez et al. 2001, Rowan et al. 2000b, See et al. 2001), and ER $\alpha$ and $\operatorname{ER} \beta$ phosphorylation has been shown to influence their interactions with coactivators (Dutertre \& Smith 2003, Tremblay et al. 1999) demonstrating that the cellular environment can influence ER-coactivator activity and/or interaction.

In this study we investigated the contribution of cellular environment to the ability of the ER $\alpha$ LBD to interact with the p160 family of coactivators as well as CBP using mammalian two-hybrid and coimmunoprecipitation assays. These studies were performed in two cell lines chosen for their relative differences in AF-1 and AF-2 contributions to $\mathrm{ER} \alpha$ transcriptional activity (Smith et al. 1997, Tzukerman et al. 1994). HeLa (human cervical 
cancer) cells utilize the receptor's AF-2 activity predominantly while in HepG2 (human hepatoma) cells the receptor's AF-1 domain is required for efficient activation of target gene expression (Tzukerman et al. 1994). Furthermore, these cell lines differ in their ability to support activation of $\mathrm{ER} \alpha$ by 4-hydroxytamoxifen (4HT), a selective estrogen receptor modulator (SERM), further highlighting the influence of cellular environment on $\mathrm{ER} \alpha$ transcriptional activity. We demonstrate that while the $\operatorname{ER} \alpha \mathrm{LBD}$ binds well to p160 coactivators in both cell types, its interaction with CBP is cell-type dependent. Intriguingly, the extent of interactions between CBP and p160 are also cell-type dependent. The differences between HeLa and HepG2 cells with respect to CBP interactions with $\mathrm{ER} \alpha$ and other coactivators is consistent with the hypothesis that cellular environment influences coactivator function, and is thereby an important determinant of cell-specific ER $\alpha$ function.

\section{Materials and methods}

\section{Chemicals}

$17 \beta$-Estradiol was obtained from Sigma Chemical Company (St Louis, MO, USA). The partial antiestrogen 4-hydroxytamoxifen and the pure antiestrogen ICI 182780 were gifts of D. Salin-Drouin (Laboratoires Besins Iscovesco, Paris, France) and A. Wakeling (Zeneca Pharmaceuticals, Macclesfield, UK), respectively.

\section{Plasmids}

The pBIND vector which encodes the GAL4-DNA binding domain (amino acids 1-147) and pACT plasmid which drives the expression of herpes virus VP16 activation domain (amino acids 411-456) were obtained from Promega Corporation (Madison, WI) as was the pG5-Luc target gene, which contains 5 DNA binding sites for the GAL4 DBD and a TATA promoter upstream of a luciferase reporter gene. The expression vectors for GAL-TIF2, GAL-RAC3 and GAL-CBP have been previously described (Lonard et al. 2000) as have those for VP16-CBP and VP16-SRC-1a (Rowan et al. 2000a). The GAL-p300 expression vector was obtained from Dr Tso-Pang Yao (Duke University). The GAL-SRG-1e expression plasmid was constructed by substituting the BstZ17I-XbaI fragment of pBIND-hSRC-1a (Lonard et al. 2000) with a 270 nucleotide BstZ17I-SpeI fragment of the SRC-1e cDNA which was generated by reverse transcribing total RNA isolated from HeLa cells with SuperScript II reverse transcriptase (Life Technologies, Grand Island, NY, USA), followed by PGR amplification using 5'-TGTGTTCAG TGAAGGTGTCG-3' and 5'-GAGGATTCGAC TAGTCTGTAG-3' as primers.

The VP16-ER $\alpha$ LBD chimera expression vector was generated in pACT as follows: $882 \mathrm{bp}$ of the ER $\alpha$ LBD cDNA corresponding to amino acids 302-595 were PCR amplified from $\mathrm{pCMV}_{5} \mathrm{hER} \alpha$ (LeGoff et al. 1994) using 5'-GGGATGGGTAA GAAGAACAGCTGGCGTTGTTCG-3' and 5'TCTAGAGACTGTGGCAGGGAAACGCTCTG CG-3' as primers. The resulting PGR fragments were subcloned into pCR $3 \cdot 1$ using the TA Cloning kit (Invitrogen, Carlsbad, CA, USA), and then re-isolated as a BamHI-XbaI fragment and subcloned into the corresponding sites of pACT to generate pACT-LBD. All constructs were sequenced to verify that mutations did not occur during PCR amplifications.

\section{Cell culture and transfection}

HeLa and HepG2 cells were maintained in Dulbecco's modified Eagle's medium (DMEM) supplemented with 10\% fetal bovine serum (FBS). Twenty-four hours prior to transfections, cells were plated in six-well culture dishes at a density of $3 \times$ $10^{5}$ or $6 \times 10^{5}$ cells per well for HeLa and HepG2 cells, respectively, in phenol-red free DMEM containing 5\% charcoal-stripped fetal bovine serum (sFBS). DNAs were introduced into cells in the indicated amounts using Lipofectamine (Life Technologies) following the manufacturer's recommendations. Five hours later, serum-free medium was replaced with phenol red-free DMEM and 5\% sFBS, and 18-20 h thereafter, cells were treated with various hormones as indicated. Twenty to twenty-four hours later, cells were harvested and cellular extracts were prepared and assayed for luciferase activity using the Luciferase Assay System kit (Promega) and a Monolight 2010 Luminometer (Analytical Luminescence Laboratory, San Diego, CA, USA); values were normalized to protein content measured with Bio-Rad Protein Assay reagent (BioRad, Hercules, CA, USA). 


\section{Mammalian two-hybrid assays}

In most mammalian two-hybrid assays, HeLa or HepG2 cells were transfected with $100 \mathrm{ng}$ of the expression vectors for GAL-coactivator (pBINDSRC-1e, pBIND-TIF2, pBIND-RAC3 or pBINDCBP) along with $1000 \mathrm{ng}$ of pACT-hER $\alpha$-LBD and $1000 \mathrm{ng}$ of pG5-Luc reporter plasmid. GBP-p160 interaction assays were performed with $100 \mathrm{ng}$ pBIND-coactivator, $1000 \mathrm{ng}$ of pACTcoactivator and $1000 \mathrm{ng}$ pG5-Luc. Plasmid amounts employed in the GAL-CBP dose response curves are given in the legend to Fig. 3. Control experiments employed equivalent amounts of the pACT and pBIND empty vectors. Cells were treated with either $0 \cdot 1 \%$ ethanolic vehicle, $10^{-8} \mathrm{M} \mathrm{E} 2$ or $10^{-7} \mathrm{M} 4 \mathrm{HT}$ for $20-24 \mathrm{~h}$ prior to cell harvest and assayed as described above.

\section{Northern analysis}

Total RNA was extracted from HeLa and HepG2 cells using TRIZOL reagent (Life Technologies) according to manufacturer's protocol. Prior to RNA extraction, HeLa and HepG2 cells were treated with either vehicle, E2, 4HT or the pure antiestrogen ICI 182 780. Forty microgams per lane of total RNA were size fractionated on a $1 \cdot 2 \%$ agarose/3-[N-morpholino]propanesulfonic acid/ formaldehyde gel then transferred by capillary action to a GeneScreen Plus nylon membrane (NEN Life Sciences, Boston, MA, USA). Membranes were air-dried and UV-cross linked with a model FB-UVXL-1000 crosslinker (Fisher Scientific, Houston, TX, USA). Probes were prepared from $25 \mathrm{ng}$ of cDNA fragments for SRC-1 (nucleotides 829-1896), TIF2 (nucleotides 4204-4815), RAC3 (nucleotides 119-1062) and mouse cyclophilin (Hasel and Sutcliffe 1990) which were labeled with $\left[\alpha^{32} \mathrm{P}\right] \mathrm{dCTP}(3000 \mathrm{Ci} / \mathrm{mmol}$; ICN Biochemical Inc., Irvine, CA, USA) using the RadPrime DNA Labeling System (Life Technologies). The blots were probed overnight under high stringency conditions $\left[65^{\circ} \mathrm{C}\right.$ in hybridization buffer consisting of $0.5 \%$ SDS, $6 \times \quad$ SSG $(0.9 \mathrm{M}$ sodium chloride, 0.09 $\mathrm{M}$ sodium citrate, $\mathrm{pH} 7 \cdot 0$ ), $5 \times$ Denhart's solution (Sambrook et al. 1989) and $100 \mu \mathrm{g} / \mathrm{ml}$ of salmon sperm DNA]. After stringent washing, radiolabeled blots were subjected to autoradiography at $-80{ }^{\circ} \mathrm{C}$ using Kodak Biomax
MS films, and band intensities were quantified by scanning laser densitometry (Personal Densitometer SI, Molecular Dynamics, Sunnyvale, CA, USA). Blots were subsequently stripped and reprobed with cyclophilin for standardization.

\section{Western analysis}

For measurement of CBP levels, HeLa and HepG2 cells were lysed in modified RIPA buffer $[50 \mathrm{mM}$ Tris-HCl (pH 7·4) containing 1\% NP-40, 0.25\% sodium deoxycholate, $150 \mathrm{mM} \mathrm{NaCl}, 1 \mathrm{mM}$ EGTA, $1 \mathrm{mM}$ PMSF, $1 \mu \mathrm{g} / \mathrm{ml}$ aprotonin, $1 \mu \mathrm{g} / \mathrm{ml}$ leupeptin, $1 \mu \mathrm{g} / \mathrm{ml}$ pepstatin, $1 \mathrm{mM} \mathrm{Na}_{3} \mathrm{VO}_{4}$, $1 \mathrm{mM} \mathrm{NaF}$. After mixing with SDS-PAGE loading buffer, protein was resolved by $7 \cdot 5 \%$ SDS-PAGE and electrophoretically transferred onto a nitrocellulose membrane (Osmonics Inc., Westborough, MA). CBP protein was detected immunochemically using CBP antibodies from Upstate Biotechnology (Lake Placid, NY, USA; CBP-CT), Affinity Bioreagents (Golden, Co) or from Santa Cruz Biotechnology (Santa Cruz, CA, USA; A-22). Donkey anti-rabbit conjugated horseradish peroxidase (HRP) antibody (Amersham, Piscataway, NJ, USA) was used for detection. For Western analysis of p160 expression levels in HeLa and HepG2 cells $50 \mu \mathrm{g}$ of total proteins extracted with lysis buffer [50 mM HEPES (pH 7.5), $100 \mathrm{mM} \mathrm{KCl,} \mathrm{0.2} \mathrm{mM}$ EDTA and $0 \cdot 1 \%$ NP40 supplemented with Complete Mini-Tablets protease inhibitor tablets (Roche Applied Sciences, Indianapolis, IN, USA)]. were separated by $6.5 \%$ SDS-PAGE. The blots were probed with either anti-SRC-1 (GeneTex, San Antonio, TX, USA), anti-TIF2 or anti-AIB1 antibodies (the latter two from BD Biosciences, San Diego, CA, USA). Anti-mouse conjugated to HRP (Amersham Biosciences) was used as secondary antibody. Visualization of specifically bound proteins was accomplished with ECL+PLUS reagent from Amersham, according to the manufacturer's protocol using XL-1 Blue film (Kodak, Rochester, NY, USA). Band intensities were quantified by scanning laser densitometry.

\section{Coimmunoprecipitation}

For coimmunoprecipitation, four plates containing $5 \times 10^{6}$ of either HeLa or HepG2 cells were harvested and incubated for 30-60 min on ice using lysis buffer similar to the one used above for 
p160 Western analysis. Following that, the cell lysate was centrifuged for $5 \mathrm{~min}$ at $21000 \times \boldsymbol{g}$, and the protein content of the lysate was quantified using Bio-Rad Protein Assay reagent. Prior to immunocomplex preparation, $100 \mathrm{ng}$ of recombinant ERa (Panvera, Madison, WI, USA) was incubated with either ethanol or $270 \mathrm{ng}$ of estradiol for $30 \mathrm{~min}$ in $30 \mu \mathrm{l}$ of buffer [ $50 \mathrm{mM}$ Tris- $\mathrm{HCl}(\mathrm{pH}$ 7.5), $10 \mathrm{mM} \mathrm{MgCl}_{2}, 1 \mathrm{mM}$ EGTA, and $2 \mathrm{mM}$ dithiothreitol]. The immunocomplex was prepared in a total volume of $1 \mathrm{ml}$ that contained $60 \mu \mathrm{l}$ of prewashed protein $\mathrm{G}+$ agarose beads, $0.5 \mathrm{mg}$ cell lysate, $100 \mathrm{ng}$ of prebound $\mathrm{ER} \alpha$, and either $1 \mu \mathrm{g}$ of anti-CBP antibody (C-1; Santa Cruz Biotechnology) or $1 \mu \mathrm{g}$ of anti-SRC-1 antibody (GeneTex, San Antonio, TX, USA). The immunocomplex was rotated at $4{ }^{\circ} \mathrm{C}$ for $1.5 \mathrm{~h}$ then centrifuged and washed three times with lysis buffer. Subsequently, the immunocomplex was boiled for $5 \mathrm{~min}$ in $50 \mu \mathrm{l}$ of $2 \times$ Laemmli solution and resolved by $7.5 \%$ SDS-PAGE and transfered to nitrocellulose membrane and probed with rat anti-human $\mathrm{ER} \alpha$ antibody (H222) followed by goat anti-rat HRP.

\section{Results}

\section{Interaction of p160 coactivators with the ER $\alpha$ LBD}

To examine the influence of cellular environment on interactions between p160 coactivators and the ligand binding domain of $\mathrm{ER} \alpha$, a mammalian two-hybrid assay was established. HeLa or HepG2 cells were transfected with expression vectors for the GAL4 DBD (GAL) or each of the chimeras of GAL fused to the amino termini of full length SRG-1, TIF2 or RAC3 in the presence of the VP16 activation domain alone (VP16) or VP16 fused to the amino-terminus of the $\mathrm{ER} \alpha \mathrm{LBD}$ (VP16-LBD). In contrast to other studies (Harnish et al. 2000, Mak et al. 1999), the GAL-coactivator constructs employed in this report encompassed the full-length forms of coactivators to ensure that the influence of regions apart from the previously defined primary interaction sites was taken into account (Heery et al. 1997). Therefore, when GAL-coactivator expression vectors were introduced into cells in the absence of $\mathrm{ER} \alpha$, the intrinsic transcriptional activity of SRG-1, TIF2 and RAC3 was apparent in comparison to the GAL4 DBD alone (Fig. 1A and B). Cotransfection of VP16LBD with either GAL-SRG-1, GAL-TIF2 or GAL-RAC3 into HeLa cells further increased luciferase activity 3.5- to 6-fold indicating an interaction between receptor and each coactivator in the absence of hormonal stimulation (Fig. 1A). This is in consistent with a previous study from our lab showing that p160/SRC coactivators and CBP can interact with $\mathrm{ER} \alpha$ in a ligand independent manner and that this interaction can be regulated by phosphorylation (Dutertre \& Smith 2003, Stenoien et al. 2001a). Control luciferase values obtained for cells transfected with expression vectors for the GAL4 DBD in the presence of VP16 or VP16-LBD, or GAL-coactivator with VP16 were very low. Estradiol treatment significantly increased luciferase activity indicating a ligand-dependent enhancement of the $\mathrm{ER} \alpha \mathrm{LBD}$ interaction with SRC-1, TIF2 and RAC3. Treatment with the partial antiestrogen $4 \mathrm{HT}$ reduced luciferase expression below vehicle controls consistent with a reduction in basal interaction between coactivators and the ER $\alpha$ LBD. Simultaneous treatment of cells with $10 \mathrm{nM} \mathrm{E2}$ and increasing concentrations of $4 \mathrm{HT}(0 \cdot 1 \rightarrow 100 \mathrm{nM})$ or $100 \mathrm{nM}$ of ICI 182780 inhibited interaction between receptor and each of the coactivators tested in a dose-dependent fashion (data not shown) further illustrating the ability of ligands to modulate this interaction. Similar results were obtained for HepG2 cells (Fig. 1B). Taken together, these results indicate that pl60 coactivators interact with the ER $\alpha$ LBD in both HeLa and HepG2 cells.

\section{Cell-specific interactions between CBP and the ER $\alpha$ LBD}

CBP also contributes to steroid receptor transcriptional activity, and we therefore tested CBP's ability to interact with the ER $\alpha$ LBD in HeLa and HepG2 cells cotransfected with GAL-CBP and the VP16-LBD chimera described above in cells treated with vehicle, $10 \mathrm{nM}$ E2 or $100 \mathrm{nM} 4 \mathrm{HT}$. Similar to the results obtained for SRC family coactivators, an E2-dependent increase in LBDCBP interaction was observed in HeLa cells (Fig. 2A). Surprisingly, however, luciferase activity in HepG2 cells transfected with GAL-CBP and VP16 was similar to that measured for cells transfected with GAL-CBP and VP16-LBD, even after E2 treatment, indicating that LBD-CBP 
A

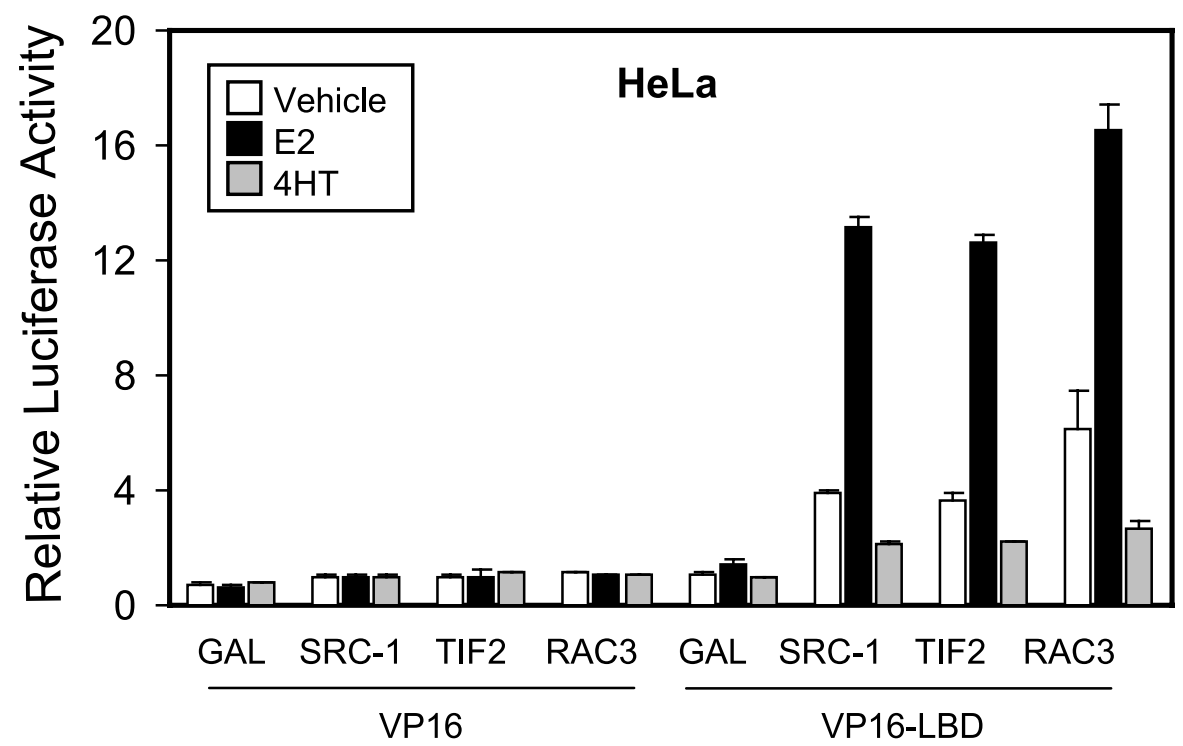

B

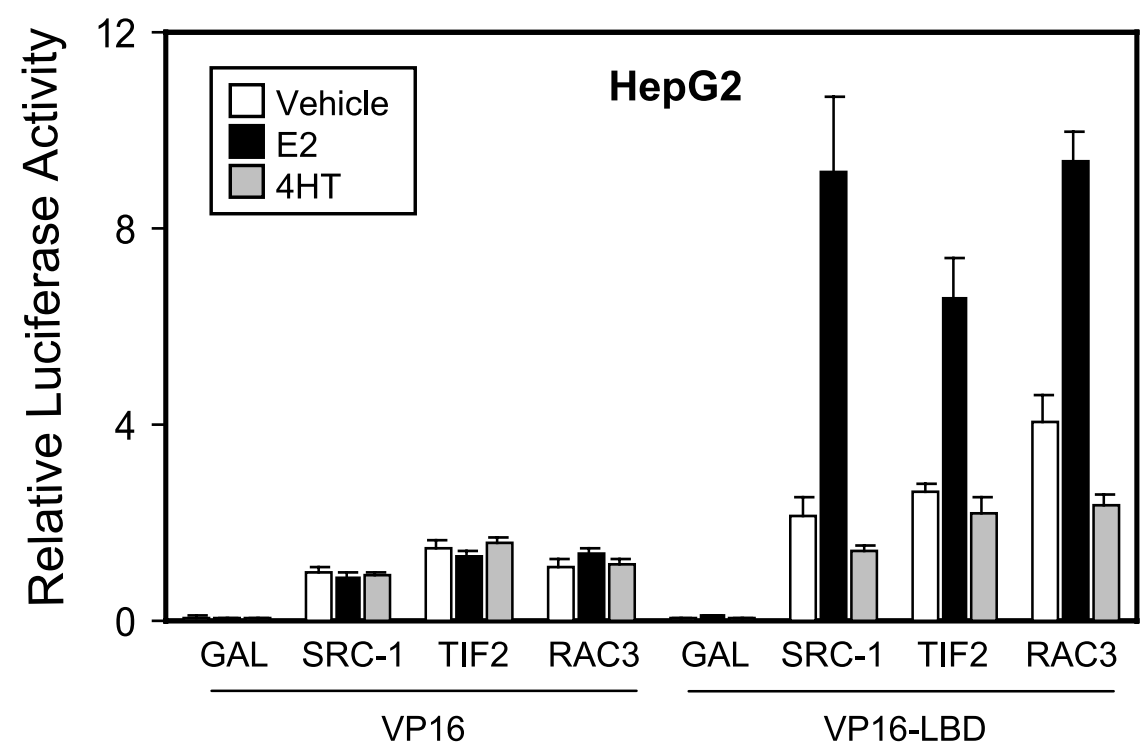

Figure 1 Mammalian two-hybrid assay of SRC family coactivator interactions with the ER $\alpha$ LBD. (A) HeLa or (B) HepG2 cells were transfected with expression vectors for the GAL4 DBD alone (GAL) or GAL-SRC-1 (SRC-1), GAL-TIF2 (TIF2) or GAL-RAC3 (RAC3) chimeras in the presence of an expression vector for VP16 alone (VP16) or a chimera consisting of the VP16 activation domain fused to the amino-terminus of the ER $\alpha$ LBD (VP16-LBD) along with the pG5-Luc reporter plasmid as indicated in the Experimental Procedures. Cells were treated with $0.1 \%$ ethanol (vehicle), $10 \mathrm{nM}$ E2 or $100 \mathrm{nM} 4 \mathrm{HT}$ for 20-24 h. Cells were subsequently harvested and assayed for luciferase activity as described in the Materials and Methods. Values are normalized to those obtained for GAL-SRC-1 and VP16 in the presence of vehicle, which were defined as '1'. Bars represent the average \pm S.E.M. of triplicate samples and are representative of at least 3 experiments. 
A

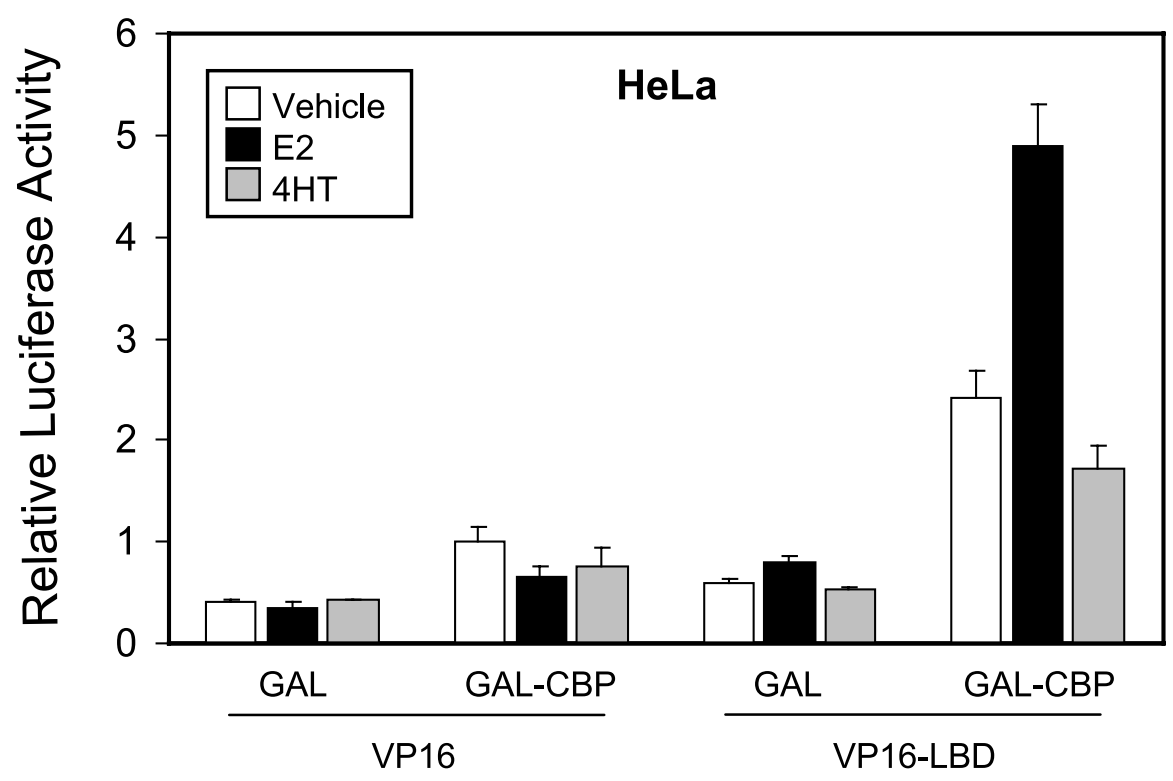

B

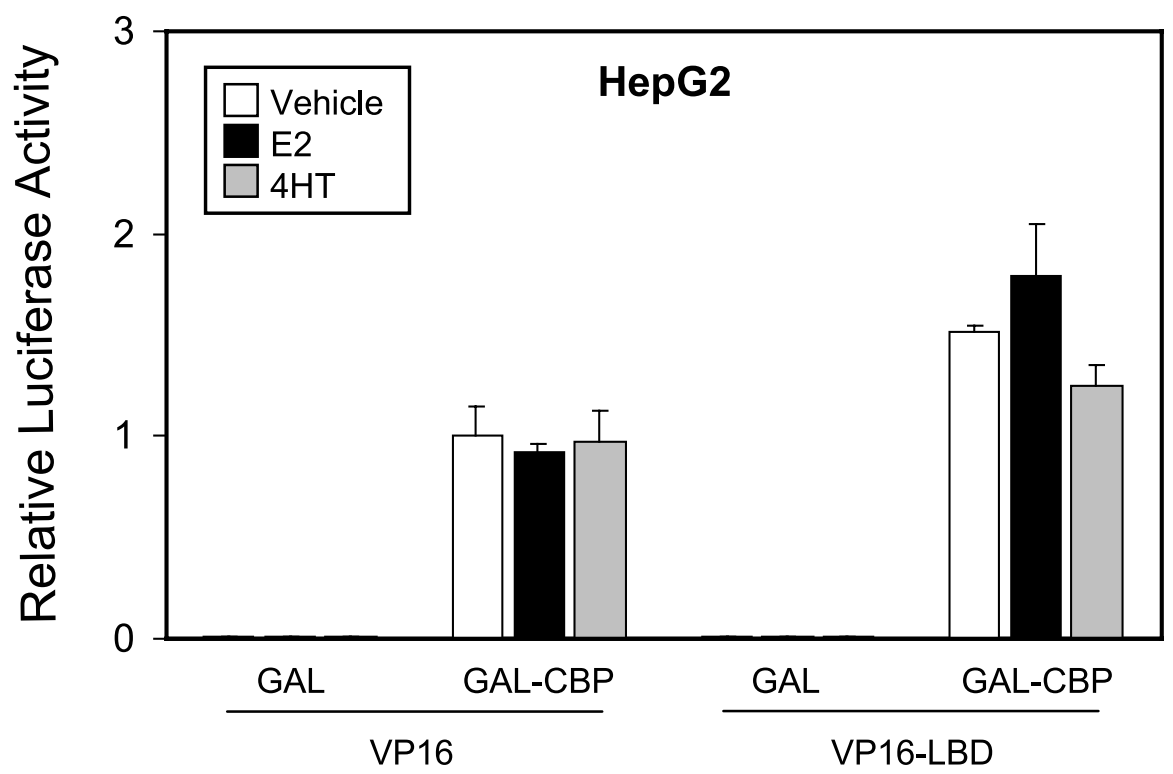

Figure 2 Cellular environment influences interactions between CBP and the ER $\alpha$ LBD. (A) HeLa or (B) HepG2 cells were transfected with expression vectors for the GAL4 DBD alone (GAL) or a GAL-CBP chimera in the presence of an expression vector for VP16 alone or VP16-LBD along with the pG5-Luc reporter plasmid. Cells were treated with $0.1 \%$ ethanol (vehicle), $10 \mathrm{nM}$ E2 or $100 \mathrm{nM} 4 \mathrm{HT}$ for $20-24 \mathrm{~h}$, and subsequently harvested and assayed for luciferase activity. Values are normalized to those obtained for GAL-CBP and VP16 in the presence of vehicle which was defined as ' 1 '. Bars represent the average \pm S.E.M. of triplicate samples and are representative of at least 3 experiments.

interactions are very weak to nondetectable (Fig. 2B). In HepG2 cells, the apparent intrinsic transcriptional activity of GAL-CBP (e.g. in the presence of VP16 alone) was 100-150-fold greater in comparison to that measured for the GAL4 DBD alone, while the differences in these 
values in HeLa cells were much less pronounced; this was also the case for GAL-p160 versus GAL activity (see Fig. 1). Therefore, to ensure that the apparent lack of ER-CBP interaction in HepG2 cells was not due to CBP's intrinsic transcriptional activity masking the activity of VP16 alone, we compared the transcriptional activity of GALVP16 to that of GAL-CBP in a dose-response experiment in both HeLa and HepG2 cells. In both cases, VP16 activity was greater than GBP (data not shown). Both of these findings argue against the possibility that CBP recruitment of VP16-LBD would be undetectable in our HepG2 cell two-hybrid assay due to relatively poor VP16 transcriptional activity. Thus, while the interactions between p160 coactivators and the ER $\alpha$ LBD are similar in HeLa and HepG2 cells, robust CBP-LBD interaction is only observed for HeLa cells.

As a further control to ensure that the apparent lack of CBP-ER $\alpha$ interaction in HepG2 cells was not due to saturation of the transcriptional machinery by high levels of intrinsic GAL-CBP activity in the cells, mammalian two-hybrid assays were performed using lower levels of GAL-CBP than used in the previous assay (10, 25, 50 and $100 \mathrm{ng}$ ) along with a fixed amount of VP16-LBD and pG5-Luc reporter. As shown for HeLa cells (Fig. 3A), there was a dose-dependent increase in luciferase activity measured in cells transfected with increasing amounts of GAL-CBP and VP16 in the presence of vehicle or estrogen. At each GAL-CBP dose, transfection of VP16-LBD resulted in an increase in luciferase activity in the absence of ligand that was further increased by estrogen treatment, confirming the results obtained in Fig. 2A. In contrast, curves obtained for HepG2 cells transfected with GAL-CBP and either VP16 or VP16-LBD were overlapping, regardless of estrogen treatment (Fig. 3B). This was not due to GAL-CBP saturation of reporter gene expression since transfection of increasing amounts of GALGBP expression vector yielded a dose-dependent increase in luciferase activity (Fig. 3B, inset).

To further support the mammalian two-hybrid results, we examined $\mathrm{CBP}$ interactions with full-length $\mathrm{ER} \alpha$ by coimmunoprecipitation. Equal amounts of full-length recombinant $\operatorname{ER} \alpha$ were added to either HeLa or HepG2 cell lysates. Following CBP coimmunoprecipitation, Western blotting for ER $\alpha$ demonstrated that E2 induces
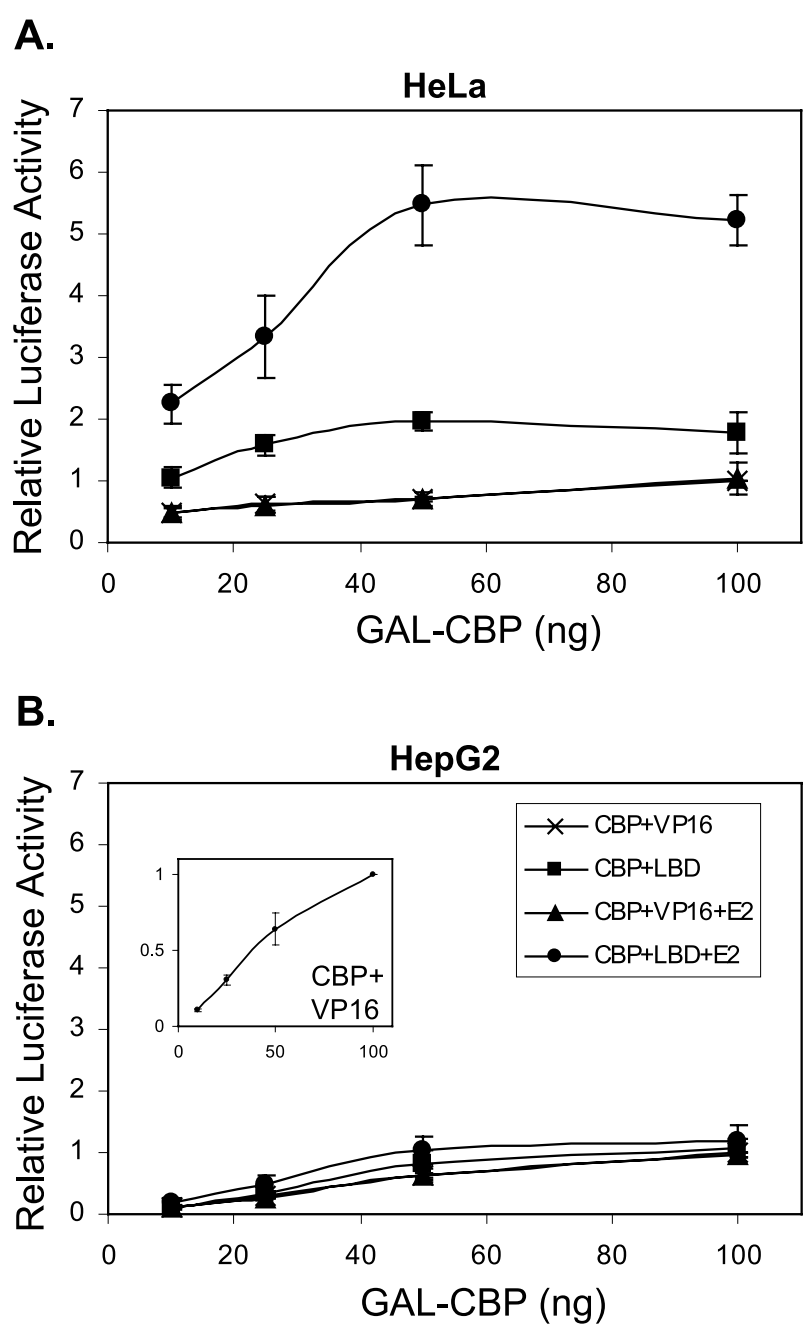

Figure 3 Dose-responsive interaction between GAL-CBP and the ER $\alpha$ LBD in HeLa cells. (A) HeLa or (B) HepG2 cells were transfected with expression vectors for increasing amounts of a GAL-CBP chimera $(10 \rightarrow 100 \mathrm{ng})$ in the presence of $1000 \mathrm{ng}$ of expression vector for VP16 or VP16-LBD chimera along with $1 \mu \mathrm{g}$ of the pG5-Luc reporter plasmid. Cells were treated with $0.1 \%$ ethanol (vehicle), $10 \mathrm{nM}$ E2 or $100 \mathrm{nM} 4 \mathrm{HT}$ for 20-24 h, and subsequently harvested for luciferase activity assay. Values are normalized to those obtained for $100 \mathrm{ng}$ GAL-CBP+VP16 in the presence of vehicle (defined as ' 1 '). Points represent the average \pm S.E.M. of three independent experiments. The inset in panel $B$ presents the values obtained for $G A L-C B P+V P 16$ and demonstrates a dose-dependent increase in GAL-CBP activity in HepG2 cells.

interaction between ER $\alpha$ and CBP in HeLa cells (Fig. 4A, top panel). Moreover, this experiment confirmed that the GBP-ER $\alpha$ interaction in HepG2 cells is weak and not hormone regulated. In 


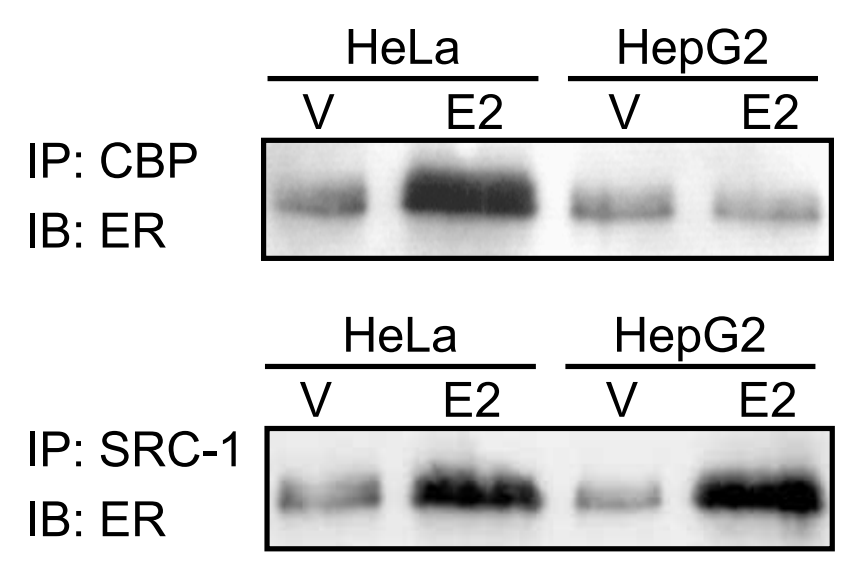

B
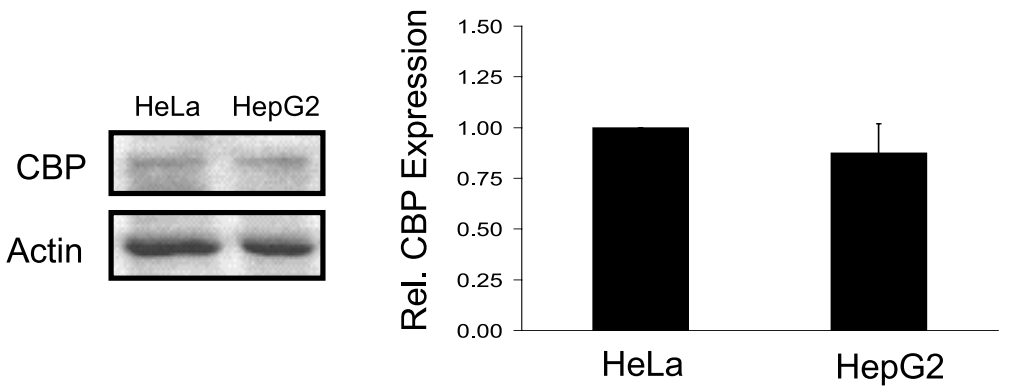

Figure $4 \mathrm{CBP}$ and SRC-1 interaction with full length $\mathrm{ER} \alpha$ in vitro. (A) One hundred nanograms of full length recombinant ER $\alpha$ previously incubated with either ethanol or $270 \mathrm{ng}$ of E2, was added to either Hela or HepG2 cell lysates and subjected to coimmunoprecipitation with antibodies against CBP (top) or SRC-1 (bottom). The ER $\alpha$ content of the immunocomplex was assessed by Western blot with ani-ER $\alpha$ antibody. (B) As a control, HeLa and HeG2 cell lysates were analyzed by Western analysis for expression of endogenous levels of CBP compared with actin (left panel). The results of 3 experiments, as quantified by laser-scanning desitometer were normalized to those obtained for HeLa cells which were defined as '1' (right panel). Bars represent the average \pm S.E.M. of three experiments. IP, immunoprecipitation; IB, immunoblot.

contrast to ER $\alpha$-CBP binding, ER $\alpha$-SRC-1 levels of interaction were comparable; in both cell types E2 enhances ER-SRG-1 interaction (Fig. 4A bottom panel). These results are consistent with our mammalian two-hybrid data indicating that CBP interaction with the $\mathrm{ER} \alpha \mathrm{LBD}$ differs between HeLa and HepG2 cells. In order to determine whether differences in endogenous expression levels of CBP might account for the very weak LBD-CBP interaction observed for HepG2 cells, CBP expression levels were assessed in HeLa and HepG2 cells by Western blot analysis. In comparison to actin levels, which were used as an internal control, CBP expression levels were similar in both cell types. Moreover, scanning densitometry of Western blots using several CBP antibodies 
showed almost equal CBP expression levels in HepG2 cells compared with HeLa cells (Fig. 4B). Mammalian two-hybrid assays demonstrate that the interaction of the p300 coactivator, which is closely related to CBP, also interacts with ER $\alpha$ in a cell-specific manner with little to no binding between these proteins in HepG2 cells (Fig. 5). Taken together, these data demonstrate that CBP and p300 interactions with the ER $\alpha$ LBD or full length $\mathrm{ER} \alpha$ are readily apparent only in HeLa cells indicating that the cellular environment influences the binding of these coactivators to $\operatorname{ER} \alpha$.

\section{Expression of SRC family coactivators are similar in HeLa and HepG2 cells}

Since p160 coactivators bind to CBP and enhance CBP physical and functional interactions with nuclear receptors (Demarest et al. 2002, Kamei et al. 1996, Li et al. 2000, Torchia et al. 1997, Voegel et al. 1998), Northern blot experiments were performed to determine whether gross differences in SRG family coactivator expression could account for differences in CBP-ER binding properties. Analyses were performed using total RNA extracted from cells exposed to either vehicle, E2, 4HT or the pure antiestrogen ICI 182780 to ensure that coactivator expression was not influenced by hormonal treatment. As shown in Fig. 6 (panels A and B), hormone treatment had no gross effects on expression levels of SRG-1, TIF2 and RAC3 mRNAs in either HeLa or HepG2 cells. SRG-1 expression was similar in both cell lines and less than 2-fold differences in mRNA levels for TIF2 and RAC3 were found between HeLa and HepG2 cells. Endogenous protein levels of p160 coactivators were also examined in HeLa and HepG2 and were found to be similar in the two cell lines (Fig. 6C). Taken together, there appear to be insufficient differences in expression of either CBP/p300 or p160 coactivators between HeLa and HepG2 cells to account for the lack of $\operatorname{ER} \alpha$ LBD interaction with CBP.

\section{Interactions between p160s and CBP are stronger in HeLa than HepG2 cells}

Since p160s and CBP bind to nuclear receptors as a ternary complex (Kamei et al. 1996, Li \& Chen 1998, Xu et al. 2000) poor receptor-p160 coactivator or $\mathrm{CBP}-\mathrm{p} 160$ coactivator interactions may compromise the ability of CBP to bind to
ER $\alpha$. Since the data in Fig. 1 demonstrate good $\mathrm{ER} \alpha$ interactions with all three p160s in both HeLa and HepG2 cells, we investigated whether the lack of CBP-ER $\alpha$ LBD binding in HepG2 cells may represent a failure of p160s to interact sufficiently well with CBP to support an ER $\alpha-\mathrm{CBP}-\mathrm{p} 160$ ternary complex. HeLa and HepG2 cells were transfected with each of the GAL-SRC-1, GALTIF2, and GAL-RAC3 expression vectors along with VP16-CBP. As shown in Fig. 7A, SRC-1, TIF2 and RAC3 interactions with CBP were very strong in HeLa cells and yielded luciferase activity 35-70 times greater than the appropriate controls. In contrast, GAL-p160 interactions with VP16CBP in HepG2 were present, but much weaker, with luciferase values only 4-6-fold higher than for GAL-p160 and VP16 alone (Fig. 7B). This finding was confirmed in a reverse two-hybrid assay between GAL-CBP and VP16-SRG-1 in which CBP-SRC-1 interactions were $\sim 4$-fold stronger in HeLa than HepG2 cells (Fig. 7C and D). Although it was noted that the magnitude of differences in interaction between cell types varied between the two-hybrid contexts, the result in both cases is the same; CBP interactions with p160s are more robust in HeLa than in HepG2 cells. Taken together, this data indicates that cellular environment affects CBP's interactions with the ER $\alpha$ LBD as well as with p160 coactivators, even though the same methodology reveals equivalent ER-p160 interactions in both HeLa and HepG2 cells, indicating that the lack of $\mathrm{CBP}-\mathrm{ER} \alpha$ binding corresponds to poor $\mathrm{CBP}-$ p160 interactions.

\section{Discussion}

The interaction between coactivators and $\operatorname{ER} \alpha$ is critical for receptor-dependent activation of target gene expression. Extensive in vitro work has characterized the basic structural requirements for receptor-coactivator binding and the role of agonistic ligands in promoting recruitment of coactivator to the LBD (Brzozowski et al. 1997, Heery et al. 1997, Henttu et al. 1997, Kalkhoven et al. 1998, Mak et al. 1999, Shiau et al. 1998). In this report we demonstrate that the interaction between the ligand binding domain of $\mathrm{ER} \alpha$ and $\mathrm{CBP} / \mathrm{p} 300$ varies between two cell lines in which the ER activation domains differ in their contribution to receptor activity (Smith et al. 1997, Tora 
A

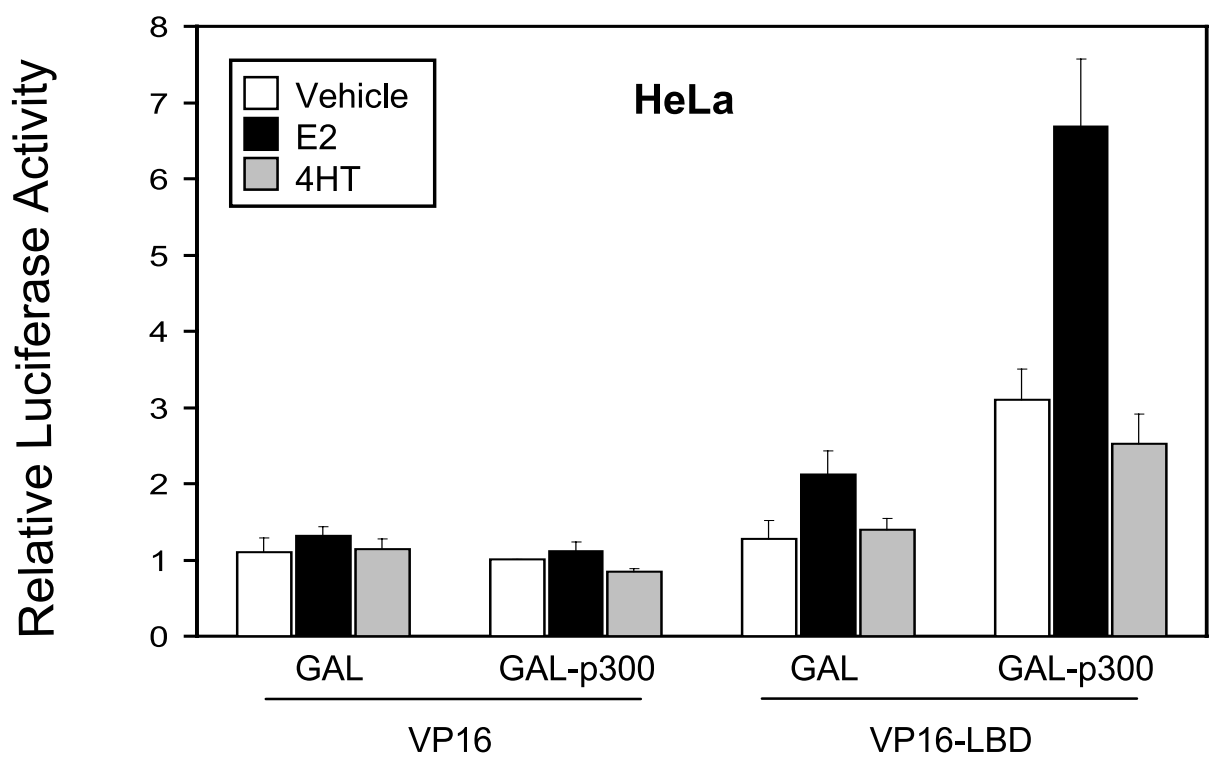

B

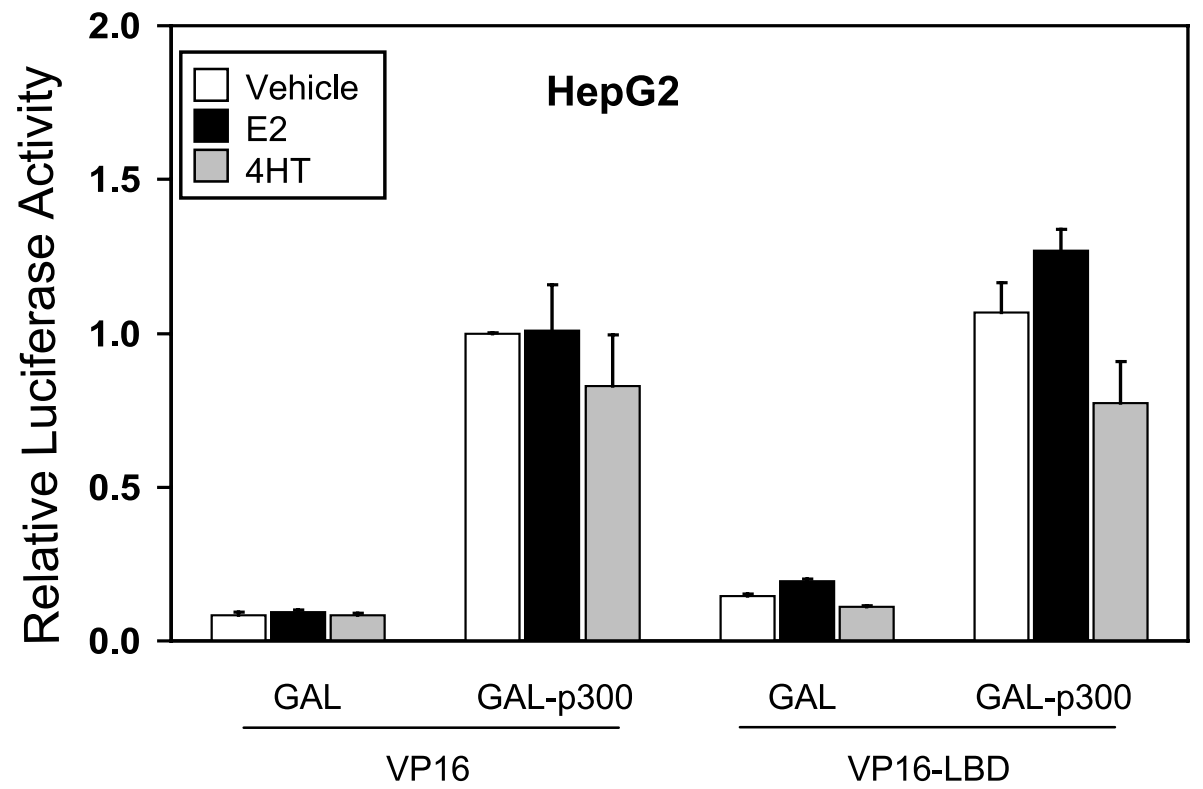

Figure 5 Cellular environment influences interactions between p300 and the ER $\alpha$ LBD. (A) HeLa or (B) HepG2 cells were transfected with expression vectors for the GAL4 DBD alone (GAL) or a GAL-p300 chimera in the presence of an expression vector for VP16 alone or VP16-LBD along with the pG5-Luc reporter plasmid. Cells were treated with $0.1 \%$ ethanol (vehicle), $10 \mathrm{nM}$ E2 or $100 \mathrm{nM} 4 \mathrm{HT}$ for 20-24 h, and subsequently harvested and assayed for luciferase activity. Values are normalized to those obtained for GAL-p300 and VP16 in the presence of vehicle which was defined as ' 1 '. Bars represent the average \pm S.E.M. of triplicate samples and are representative of at least 3 experiments. 
A
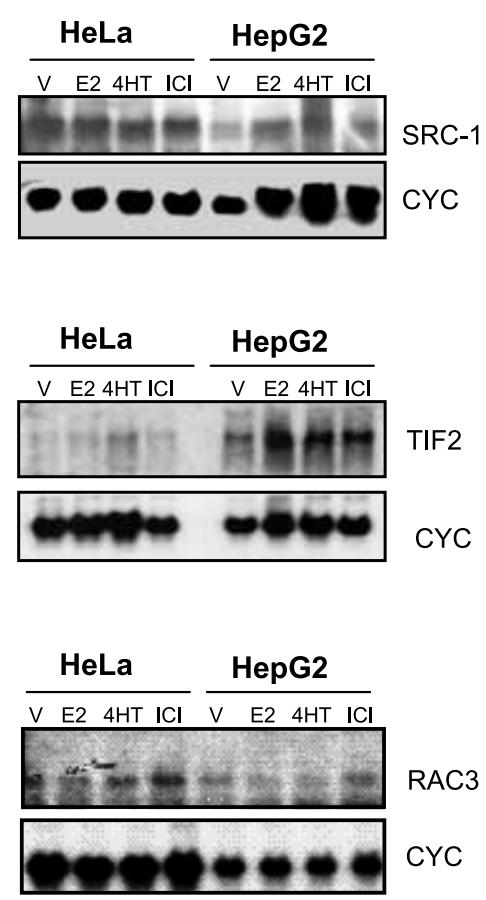

B
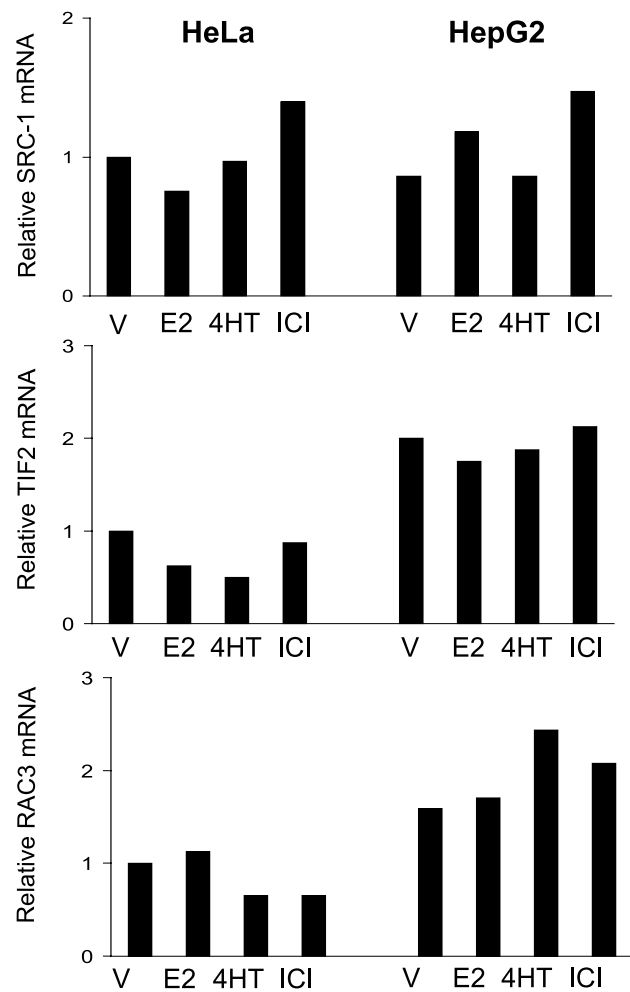

C
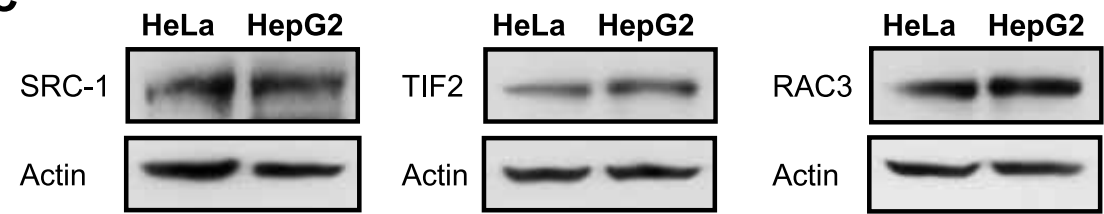

Figure 6 Endogenous expression levels of SRC family coactivators and CBP are similar in HeLa and HepG2 cells. (A) Total RNA isolated from HeLa (left) and HepG2 (right) cells which had been treated with ethanol (vehicle) or $10 \mathrm{nM} \mathrm{E2,} 100 \mathrm{nM} \mathrm{4HT}$ or $100 \mathrm{nM} \mathrm{ICl}$ $182780(\mathrm{ICl})$ for $24 \mathrm{~h}$ were subjected to Northern blot analyses using radiolabeled cDNA probes against SRC-1 (top), TIF2 (middle) or RAC3 (bottom). Blots were subsequently stripped and reprobed with a radiolabeled cyclophilin (CYC) CDNA fragment to measure cyclophilin mRNA levels, which were used as an internal control. (B) Relative normalized expression levels of SRC-1, TIF2 and RAC3 mRNAs. Laser scanning densitometer measurements of coactivator mRNAs were normalized to values obtained for cyclophilin, and the expression of each coactivator in vehicle-treated HeLa cells was arbitrarily set to '1'. (C) Fifty micrograms of HeLa and HepG2 cell lysate were subjected to Western analysis to examine endogenous levels of SRC-1, TIF2 and RAC3. Western analysis of actin levels were used to ensure equal loading.

et al. 1989, Tzukerman et al. 1994). In vivo interactions between SRC-1, TIF2 or RAC3 and the wild-type $\mathrm{ER} \alpha \mathrm{LBD}$ are hormone-dependent in both HeLa and HepG2 cells, supporting a role for these coactivators in $\mathrm{ER} \alpha$ action in both cell types.
However, very little interaction between $\mathrm{CBP}$ or p300 and the ER $\alpha$ LBD was observed in HepG2 cells in vivo and in vitro, suggesting that ER $\alpha$ transcriptional activity in this cell type may be less dependent on CBP/p300 than in HeLa cells. 
HeLa

HepG2
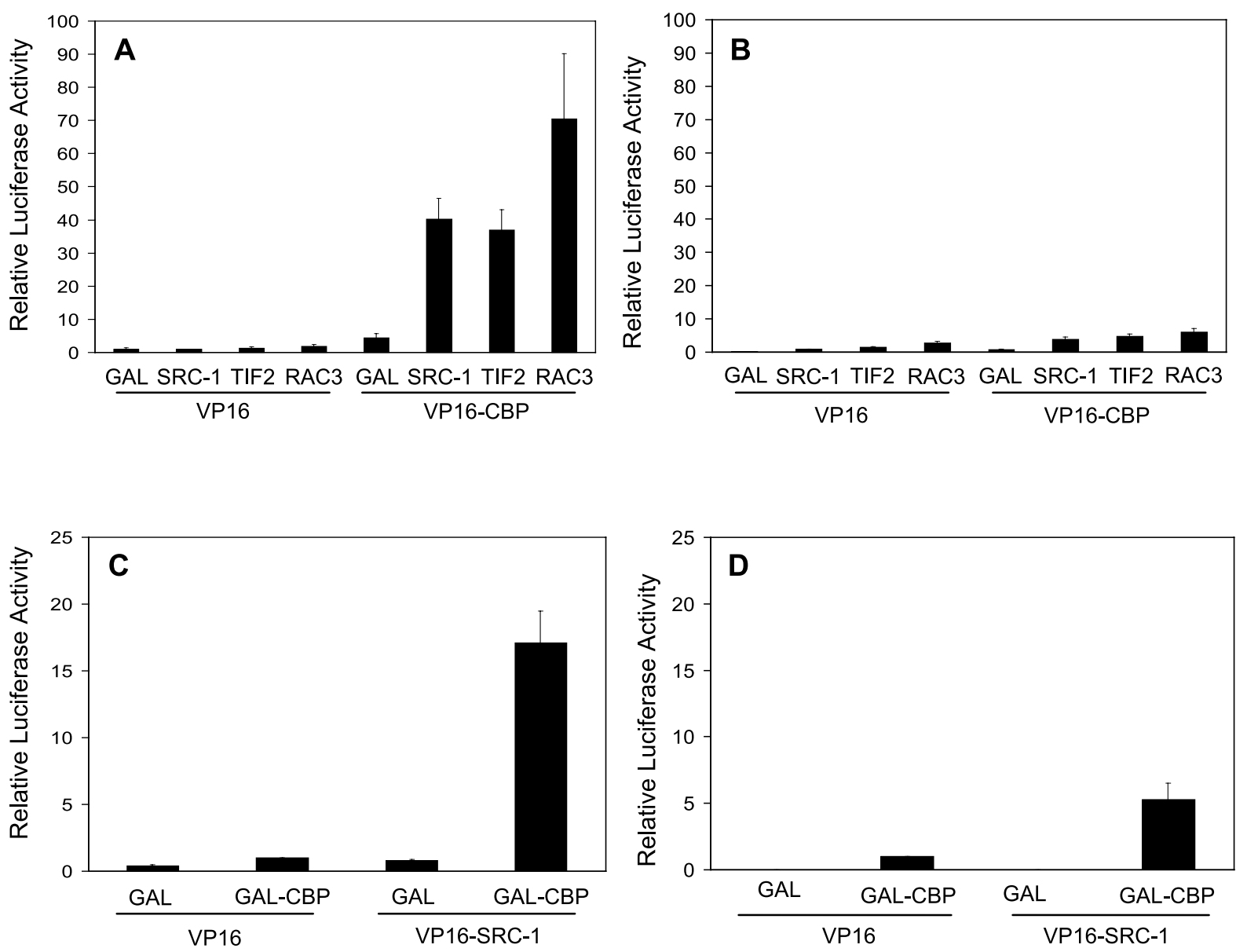

Figure 7 Cellular environment influences interactions between CBP and the p160 coactivators. HeLa (left column; panel A) or HepG2 (right column; panel B) cells were transfected with expression vectors for the GAL4 DBD alone (GAL) or GAL-SRC-1, GAL-TIF2, GAL-RAC3 in the presence of an expression vector for VP16 alone or VP16-CBP along with the pG5-Luc. Values are normalized to those obtained for Gal-SRC-1 and VP16, which was defined as '1'. HeLa (C) and HepG2 (D) cells were transfected with GAL4 alone or GAL-CBP in the presence of either VP16 alone or VP16-SRC-1 (panels $C$ and $D$ ). Values are normalized to those obtained for GAL-CBP and VP16, which was defined as '1'. Bars represent the average \pm S.E.M. of 3 individual experiments.

Although we and others had hypothesized several years ago that differences in coactivator expression could be important for influencing the nature of ER-coactivator interactions (Jackson et al. 1997, Lavinsky et al. 1998, Smith et al. 1997), here we have shown differences in coactivator-ER interactions in cells in which SRG-1, TIF2, RAC3 and CBP expression levels are comparable. Thus, cellular factors other than the ligand and the expression of the coactivators themselves such as post-translational modifications (positive or nega- tive), or the expression of other modulatory coregulators, are important determinants of receptor-coactivator interactions.

Estradiol promotes interactions of coactivators with $\mathrm{ER} \alpha$ by inducing a conformational change in the structure of the receptor's LBD. Recent crystallographic analyses of the LBDs of ER $\alpha$ and/or ER $\beta$ complexed with E2 (Brzozowski et al. 1997), diethylstilbestrol (Shiau et al. 1998), raloxifene (Brzozowski et al. 1997, Pike et al. 1999), 4HT (Shiau et al. 1998), genestein (Pike et al. 1999) 
or ICI 164384 (Pike et al. 2001) provides a structural framework within which LBDcoactivator interactions can be examined. Upon binding to an ER $\alpha$ agonist such as E2 or diethylstilbestrol, helix 12 of the LBD is oriented over the ligand-binding cavity. Helices 3, 5 and 12 in turn generate a functional $\mathrm{AF}-2$ domain consisting of a hydrophobic groove on the LBD surface (Brzozowski et al. 1997, Shiau et al. 1998), and the co-crystal structure of amino acids 686 to 698 of the NR box II peptide of glucocorticoid receptor-interacting protein-l (GRIP1) (mouse homologue of TIF2) and the LBD confirm that this receptor surface is a coactivator-binding site (Shiau et al. 1998). As anticipated, our data indicate that p160 coactivator interaction with the $\operatorname{ER} \alpha$ LBD was significantly enhanced by E2 in both HeLa and HepG2 cells, consistent with ligand-induced changes in receptor structure and formation of a coactivator-binding site. However, receptorcoactivator interaction in the absence of ligand was also observed in both cell types, and 4HT reduced this interaction below levels observed under basal conditions. In this regard, $\mathrm{ER} \alpha$ is similar to the constitutive androstane receptor- $\beta$ (CAR- $\beta$ ) that can also interact with SRC-1 in the apparent absence of ligand (Forman et al. 1998). Recent work has demonstrated that the extent of ligandindependent interactions between $\mathrm{ER} \alpha$ and coactivators is influenced by $\mathrm{ER} \alpha$ phosphorylation (Dutertre \& Smith 2003).

Although $\mathrm{CBP} / \mathrm{p} 300$ can bind to various members of the nuclear receptor superfamily (Hanstein et al. 1996, Kamei et al. 1996, Kobayashi et al. 2000), its relative importance to the transcriptional activity of steroid receptors versus its role as an integrator/coactivator for numerous types of transcription factors is not clear. This contrasts with SRG family coactivators whose actions appear to be more restricted to nuclear receptors and for which evidence of the importance of these factors to steroid receptor function is abundant (Goodman \& Smolik 2000). Nevertheless, CBP increases ER $\alpha$-dependent gene expression and/or binds to ER $\alpha$ (Kamei et al. 1996, Smith et al. 1996), and ER $\alpha$-CBP functional interactions therefore appear to be significant. Our results indicate that the cellular environment plays an important role in regulating the magnitude of CBP-LBD and CBP-p160 interactions. Both are much stronger in HeLa than HepG2 cells, suggesting that cellular factors that regulate each of these interactions may be related. This is consistent with reports indicating that $\mathrm{CBP} / \mathrm{p} 300$-receptor interactions, in the absence of p160s, are poor. For instance, p300 binds weakly to thyroid hormone receptor on its own, but the addition of SRC-1 greatly enhances p300 interaction with this receptor (Li et al. 2000). It also has been shown that the p160-binding region of CBP is required for this coactivator to stimulate retinoic acid receptor transcriptional activity (McInerney et al. 1998). Those results are in agreement with the finding that CBP, p160s and nuclear receptors binding to one another as a ternary complex (Kamei et al. 1996, Li and Chen 1998, Xu et al. 2000). Our data therefore are consistent with a model in which the inability of CBP to interact well with the ER $\alpha$ LBD in HepG2 cells is due to the relatively poor $\mathrm{CBP}-\mathrm{p} 160$ interactions observed for this cell type. Whether this is due to a negative acting factor in HepG2 cells, or lack of a positive influence in HeLa cells is currently under investigation. It is, however, unlikely to be due to failure of p160-ER $\alpha$ LBD interactions as they were quite strong in both cell types. It is important to note that CBP may still alter ER $\alpha$ transcriptional activity in HepG2 cells by indirect competition with other transcription factors or coactivators, and/or through interactions with the AF-1 domain (Kobayashi et al. 2000). Indeed, another investigator has demonstrated indirect effects of $\mathrm{ER} \alpha$ on $\mathrm{NF}-\kappa \mathrm{B}$ activity that can be partially overcome by CBP overexpression (Goff et al. 1994), suggesting that ER $\alpha-\mathrm{CBP}$ interactions may still be functionally important. Taken together, our data demonstrate that the molecular nature of ER interactions with CBP and SRC family coactivators are distinct.

Although the role of ligand in promoting interaction between nuclear receptors and different coactivators is widely recognized, there are few examples of the ability of cellular environment to alter coregulator function in a cell-type specific manner. For instance, the histone deacetylase inhibitor trichostatin A stimulates thyroid hormone receptor transcriptional activity in GH3 but not CV1 cells (Lizcano et al. 2001), while GRIP1 and RAC3 have preferential effects on stimulating vitamin D receptor activity in $\mathrm{CV} 1$ and $\mathrm{P} 19$ cells, respectively (Issa et al. 2001). Our studies provide evidence that extend these observations and demonstrate that coactivator binding to $\mathrm{ER} \alpha$ or 
other coactivators is not simply a reflection of the relative abundance of potential interacting proteins in a given cellular environment, but is also regulated by other factors within the cell. Taken together with the complexity contributed by the organizing influence of the promoter regions of $\mathrm{ER} \alpha$ target genes, the ability of $\mathrm{ER} \alpha$ to stimulate gene expression can be viewed in terms of multiple possible coactivator partners for $\mathrm{ER} \alpha$ and the ability of ER $\alpha$ to bind to these coregulators in a cell-dependent fashion. As the selectivity of SERMs is thought to depend on differences in $\mathrm{ER} \alpha$ interactions with coregulators between different cell and tissue types, these results also have important implications for understanding the molecular basis of SERM action.

\section{Acknowledgements}

The authors thank Drs Martin Dutertre, Nancy Weigel and Tso-Pang Yao for making available several of the expression vectors used in this study, and Judy Roscoe and Cheryl Parker for expert cell culture assistance. The H222 antibody was the kind gift of Abbott Laboratories (Abbott Park, IL, USA). This work was supported by grants from the National Institutes of Health (DK53002) and American Heart Association (9850078N) to GLS. RM was supported by a NIH training grant in Reproductive Biology (HD07165).

\section{References}

Anzick SL, Kononen J, Walker RL, Azorsa DO, Tanner MM, Guan XY, Sauter G, Kallioniemi OP, Trent JM \& Meltzer PS 1997 AIB1, a steroid receptor coactivator amplified in breast and ovarian cancer. Science 277 965-968.

Beekman JM, Allan GF, Tsai SY, Tsai M-J \& O’Malley BW 1993 Transcriptional activation by the estrogen receptor requires a conformational change in the ligand binding domain. Molecular Endocrinology 7 1266-1274.

Brzozowski AM, Pike AC, Dauter Z, Hubbard RE, Bonn T, Engstrom O, Ohman L, Greene GL, Gustafsson J-Å \& Carlquist M 1997 Molecular basis of agonism and antagonism in the oestrogen receptor. Nature $\mathbf{3 8 9} 753-758$.

Burakov D, Wong CW, Rachez C, Cheskis B \& Freedman LP 2000 Functional interactions between the estrogen receptor and DRIP205, a subunit of the heteromeric DRIP coactivator complex. Fournal of Biological Chemistry 275 20928-20934.

Carson-Jurica MA, Schrader WT \& O'Malley BW 1990 Steroid receptor family: structure and functions. Endocrine Reviewes $\mathbf{1 1}$ 201-220.

Chang C-Y, Norris JD, Gron H, Paige LA, Hamilton PT, Kenan DJ, Fowlkes D \& McDonnell DP 1999 Dissection of the LXXLL nuclear receptor-coactivator interaction motif using combinatorial peptide libraries: discovery of peptide antagonists of estrogen receptors $\alpha$ and $\beta$. Molecular and Cellular Biology 19 8226-8239.

Chen H, Lin RJ, Schiltz RL, Chakravarti D, Nash A, Nagy L, Privalsky ML, Nakatani Y \& Evans RM 1997 Nuclear receptor coactivator ACTR is a novel histone acetyltransferase and forms a multimeric activation complex with $\mathrm{P} / \mathrm{CAF}$ and $\mathrm{CBP} / \mathrm{p} 300$. Cell 90 569-580.

Demarest SJ, Martinez-Yamount M, Chung J, Chen H, Xu W, Dyson HJ, Evans RM \& Wright PE 2002 Mutual synergistic folding in recruitment of CBP/p300 by p160 nuclear receptor coactivators. Nature 415 549-553.

Dutertre M \& Smith CL 2003 Ligand-independent interactions of p160/SRC coactivators and CBP with estrogen receptor- $\alpha$ : Regulation by phosphorylation sites in the $\mathrm{A} / \mathrm{B}$ region depends on other receptor domains. Molecular Endocrinology 17 1296-1314.

Endoh H, Maruyama K, Masuhiro Y, Kobayashi Y, Goto M, Tai H, Yanagisawa J, Metzger D, Hashimoto S \& Kato S 1999 Purification and identification of p68 RNA helicase acting as a transcriptional coactivator specific for the activation function 1 of human estrogen receptor $\alpha$. Molecular and Cellular Biology 19 5363-5372.

Font de Mora JF \& Brown M 2000 AIB1 is a conduit for kinasemediated growth factor signaling to the estrogen receptor. Molecular and Cellular Biology 20 5041-5047.

Forman BM, Tzameli I, Choi H-S, Chen J, Simha D, Seol W, Evans RM \& Moore DD 1998 Androstane metabolites bind to and deactivate the nuclear receptor CAR- $\beta$. Nature 395 $612-615$

Glass CK \& Rosenfeld MG 2000 The coregulator exchange in transcriptional functions of nuclear receptors. Genes and Development 14 121-141.

Goff PL, Montano MM, Schodin DJ \& Katzenellenbogen BS 1994 Phosphorylation of human estrogen receptor: identification of hormone-regulated sites and examination of their influence on transcriptional activity. Fournal of Biological Chemistry 269 4458-4466.

Goodman RH \& Smolik S 2000 CBP/p300 in cell growth, transformation, and development. Genes and Development $\mathbf{1 4}$ 1553-1577.

Green S \& Chambon P 1991 The oestrogen receptor: from perception to mechanism. In Nuclear Hormone Receptors, pp 15-38. Ed MG Parker. San Diego: Academic Press Ltd.

Hanstein B, Eckner R, DiRenzo J, Halachmi S, Liu H, Searcy B, Kurokawa R \& Brown M 1996 p300 is a component of an estrogen receptor coactivator complex. PNAS 93 11540-11545.

Harnish DC, Scicchitano MS, Adelman SJ, Lyttle CR \& Karathanasis SK 2000 The role of CBP in estrogen receptor cross-talk with nuclear factor- $\mathrm{kB}$ in HepG2 cells. Endocrinology 141 3403-3411.

Hasel KW \& Sutcliffe JG 1990 Nucleotide sequence of a cDNA coding for mouse cyclophilin. Nucleic Acids Research 184019

Heery DM, Kalkhoven E, Hoare S \& Parker MG 1997 A signature motif in transcriptional co-activators mediates binding to nuclear receptors. Nature 387 733-736.

Henttu PM, Kalkhoven E \& Parker MG 1997 AF-2 activity and recruitment of steroid receptor coactivator 1 to the estrogen receptor depend on a lysine residue conserved in nuclear receptors. Molecular and Cellular Biology 17 1832-1839.

Hong H, Kohli K, Trivedi A, Johnson DL \& Stallcup MR 1996 GRIP1, a novel mouse protein that serves as a transcriptional coactivator in yeast for the hormone binding domains of steroid receptors. PNAS 93 4948-4952.

Issa LL, Leong GM, Barry JB, Sutherland RL \& Eisman JA 2001 Glucocorticoid receptor-interacting protein-1 and receptorassociated coactivator-3 differentially interact with the vitamin D receptor (VDR) and regulate VDR-retinoid X receptor transcriptional cross-talk. Endocrinology 142 1606-1615. 
Jackson TA, Richer JK, Bain DL, Takimoto GS, Tung L \& Horwitz KB 1997 The partial agonist activity of antagonist-occupied steroid receptors is controlled by a novel hinge domain-binding coactivator L7/SPA and the corepressors N-CoR or SMRT. Molecular Endocrinology 11 693-705.

Jacq X, Brou C, Lutz Y, Davidson I, Chambon P \& Tora L 1994 Human $\mathrm{TAF}_{\mathrm{II}} 30$ is present in a distinct TFIID complex and is required for transcriptional activation by the estrogen receptor. Cell 79 107-117.

Kalkhoven E, Valentine JE, Heery DM \& Parker MG 1998 Isoforms of steroid receptor co-activator 1 differ in their ability to potentiate transcription by the oestrogen receptor. EMBO fournal 17 232-243.

Kamei Y, Xu L, Heinzel T, Torchia J, Kurokawa R, Gloss B, Lin S-C, Heyman RA, Rose DW, Glass CK \& Rosenfeld MG 1996 A $\mathrm{CBP}$ integrator complex mediates transcriptional activation and AP-1 inhibition by nuclear receptors. Cell 85 403-414.

Katzenellenbogen JA, O’Malley BW \& Katzenellenbogen BS 1996 Tripartite steroid hormone receptor pharmacology: interaction with multiple effector sites as a basis for the cell- and promoterspecific action of these hormones. Molecular Endocrinology 10 119-131.

Kobayashi Y, Kitamoto T, Masuhiro Y, Watanabe M, Kase T, Metzger D, Yanagisawa J \& Kato S 2000 p300 mediates functional synergism between AF-1 and AF-2 of estrogen receptor $\alpha$ and $\beta$ by interacting directly with the $\mathrm{N}$-terminal $\mathrm{A} / \mathrm{B}$ domains. Fournal of Biological Chemistry 275 15645-15651.

Kraus WL \& Kadonaga JT 1998 p300 and estrogen receptor cooperatively activate transcription via differential enhancement of initiation and reinitiation. Genes and Development 12 331-342.

Lavinsky RM, Jepsen K, Heinzel T, Torchia J, Mullen T-M, Schiff R, Del-Rio AL, Ricote M, Ngo S, Gemsch J, Hilsenbeck SG, Osborne CK, Glass CK, Rosenfeld MG \& Rose DW 1998 Diverse signaling pathways modulate nuclear receptor recruitment of N-CoR and SMRT complexes. PNAS 95 2920-2925.

Lees JA, Fawell SE \& Parker MG 1989 Identification of constitutive and steroid-dependent transactivation domains in the mouse oestrogen receptor. Fournal of Steroid Biochemistry 34 33-39.

LeGoff P, Montano MM, Schodin DJ \& Katzenellenbogen BS 1994 Phosphorylation of the human estrogen receptor. Identification of hormone-regulated sites and examination of their influence on transcriptional activity. Fournal of Biological Chemistry $\mathbf{2 6 9}$ 4458-4466.

Li H \& Chen JD 1998 The receptor-associated coactivator 3 activates transcription through CREB-binding protein recruitment and autoregulation. Foumal of Biological Chemistry 273 5948-5954.

Li H, Gomes PJ \& Chen JD 1997 RAC3, a steroid/nuclear receptor-associated coactivator that is related to SRC-1 and TIF2. PNAS 94 8479-8484.

Li J, O'Malley BW \& Wong J 2000 p300 requires its histone acetyltransferase activity and SRC-1 interaction domain to facilitate thyroid hormone receptor activation in chromatin. Molecular and Cellular Biology 20 2031-2042.

Lizcano F, Koibuchi N, Fukuda H, Dangond F \& Chin WW 2001 Cell type-specific roles of histone deacetylase in TR ligandindependent transcriptional repression. Molecular and Cellular Endocrinology 172 13-20.

Llopis J, Westin S, Ricote M, Wang J, Cho CY, Kurokawa R, Mullen T-M, Rose DW, Rosenfeld MG, Tsien RY \& Glass CK 2000 Ligand-dependent interactions of coactivators steroid receptor coactivator-1 and peroxisome proliferator-activated receptor binding protein with nuclear hormone receptors can be imaged in live cells and are required for transcription. PNAS $\mathbf{9 7}$ 4363-4368.

Lonard DM, Nawaz Z, Smith CL \& O’Malley BW 2000 The 26S proteasome is required for estrogen receptor- $\alpha$ and coactivator turn-over and for efficient estrogen receptor- $\alpha$ transactivation. Molecular Cell 5 939-948.

Lopez GN, Turck CW, Schaufele F, Stallcup MR \& Kushner PJ 2001 Growth factors signal to steroid receptors through mitogen-activated protein kinase regulation of p160 co-activator activity. Fournal of Biological Chemistry 276 22177-22182.

McDonnell DP, Glemm DL, Hermann T, Goldman ME \& Pike JW 1995 Analysis of estrogen receptor function in vitro reveals three distinct classes of antiestrogens. Molecular Endocrinology $\mathbf{9}$ 659-669.

McInerney EM, Tsai M-J, O’Malley BW \& Katzenellenbogen BS 1996 (b) Analysis of estrogen receptor transcriptional enhancement by a nuclear hormone receptor coactivator. PNAS $\mathbf{9 3}$ 10069-10073.

McInerney EM, Rose DW, Flynn SE, Westin S, Mullen T-M, Krones A, Inostroza J, Torchia J, Nolte RT, Assa-Munt N, Milburn MV, Glass CK \& Rosenfeld MG 1998 (a) Determinants of coactivator LXXLL motif specificity in nuclear receptor transcriptional activation. Genes and Development 12 3357-3368.

McKenna NJ, Lanz RB \& O’Malley BW 1999 Nuclear receptor coregulators: cellular and molecular biology. Endocrine Reviewes 20 321-344.

Mak HY, Hoare S, Henttu PMA \& Parker MG 1999 Molecular determinants of the estrogen receptor-coactivator interface. Molecular and Cellular Biology 19 3895-3903.

Montano MM, Muller V, Trobaugh A \& Katzenellenbogen BS 1995 The carboxy-terminal $\mathrm{F}$ domain of the human estrogen receptor: role in the transcriptional activity of the receptor and the effectiveness of antiestrogens as estrogen antagonists. Molecular Endocrinology $9814-825$.

Nawaz Z, Lonard DM, Smith CL, Lev-Lehman E, Tsai SY, Tsai M-J \& O'Malley BW 1999 The Angelman syndromeassociated protein, E6-AP, is a coactivator for the nuclear hormone receptor superfamily. Molecular and Cellular Biology 19 1182-1189.

Nichols M, Rientjes JMJ \& Stewart AF 1998 Different positioning of the ligand-binding domain helix 12 and the $\mathrm{F}$ domain of the estrogen receptor accounts for functional differences between agonists and antagonists. EMBO fournal 17 765-773.

Norris JD, Fans D, Stallcup MR \& McDonnell DP 1998 Enhancement of estrogen receptor transcriptional activity by the coactivator GRIP-1 highlights the role of activation function 2 in determining estrogen receptor pharmacology. Fournal of Biological Chemistry 273 6679-6688.

Onate SA, Tsai SY, Tsai M-J \& O’Malley BW 1995 Sequence and characterization of a coactivator for the steroid hormone receptor superfamily. Science 270 1354-1357.

Pike AC, Brzozowski AM, Hubbard RE, Bonn T, Thorsell AG, Engstrom O, Ljunggren J, Gustafsson J-A \& Carlquist M 1999 Structure of the ligand-binding domain of oestrogen receptor beta in the presence of a partial agonist and a full antagonist. EMBO fournal 18 4608-4618.

Pike AC, Brzozowski AM, Walton J, Hubbard RE, Thorsell AG, Li Y-L, Gustafsson J-Å \& Carlquist M 2001 Structural insights into the mode of action of a pure antiestrogen. Structure $\mathbf{9}$ 145-153.

Porter W, Saville B, Hoivik D \& Safe S 1997 Functional synergy between the transcription factor $\mathrm{Spl}$ and the estrogen receptor. Molecular Endocrinology 11 1569-1580.

Robyr D, Wolffe AP \& Wahli W 2000 Nuclear hormone receptor coregulators in action: diversity for shared tasks. Molecular Endocrinology 14 329-347.

Rowan BG, Weigel NL \& O'Malley BW 2000a Phosphorylation of steroid receptor coactivator-1. Identification of the phosphorylation sites and phosphorylation through the mitogen-activated protein kinase pathway. Fournal of Biological Chemistry 275 4475-4483. 
Rowan BG, Garrison N, Weigel NL \& O'Malley BW $2000 b$ 8-bromo-cyclic AMP induces phosphorylation of two sites in SRC-1 that facilitate ligand-independent activation of the chicken progesterone receptor and are critical for functional cooperation between SRC-1 and CREB binding protein. Molecular and Cellular Biology 20 8720-8730.

Sambrook J, Fritsch EF \& Maniatis T 1989 Molecular cloning: A laboratory manual, edn 2, p B-15. Cold Spring Harbor: Cold Spring Harbor Press.

See RH, Calvo D, Shi Y, Kawa H, Luke MP-S, Yuan Z \& Shi Y 2001 Stimulation of p300-mediated transcription by the kinase MEKK1. Fournal of Biological Chemistry 276 16310-16317.

Shang Y, Hu X, DiRenzo J, Lazar MA \& Brown M 2000 Cofactor dynamics and sufficiency in estrogen receptor-regulated transcription. Cell 103 843-852.

Shiau AK, Barstad D, Loria PM, Cheng L, Kushner PJ, Agard DA \& Greene GL 1998 The structural basis of estrogen receptor/ coactivator recognition and the antagonism of this interaction by tamoxifen. Cell 95 927-937.

Smith CL, Onate SA, Tsai M-J \& O'Malley BW 1996 CREB binding protein acts synergistically with steroid receptor coactivator-1 to enhance steroid receptor-dependent transcription. PNAS $938884-8888$.

Smith CL, Nawaz Z \& O’Malley BW 1997 Coactivator and corepressor regulation of the agonist/antagonist activity of the mixed antiestrogen, 4-hydroxytamoxifen. Molecular Endocrinology 11 657-666.

Stenoien DL, Mancini MG, Patel K, Allegretto EA, Smith CL \& Mancini MA 2000 Subnuclear trafficking of estrogen receptor- $\alpha$ and steroid receptor coactivator-1. Molecular Endocrinology 14 $518-534$.

Stenoien DL, Nye AC, Mancini MG, Patel K, Dutertre M, O'Malley BW, Smith CL, Belmont AS \& Mancini MA $2001 a$ Ligand-mediated assembly and real-time cellular dynamics of estrogen receptor- $\alpha /$ coactivator complexes in living cells. Molecular and Cellular Biology $214404-4412$.

Stenoien DL, Patel K, Mancini MG, Dutertre M, Smith CL, O'Malley BW \& Mancini M $2001 b$ FRAP reveals that mobility of oestrogen receptor-a is ligand- and proteasome-dependent. Nature Cell Biology 3 15-23.

Takeshita A, Cardonna GR, Koibuchi N, Suen C-S \& Chin WW 1997 TRAM-1, a novel 160-kDa thyroid hormone receptor activator molecule, exhibits distinct properties from steroid receptor coactivator-1. Journal of Biological Chemistry 272 27629-27634.

Tikkanen MK, Carter DJ, Harris AM, Le HM, Azorsa DO, Meltzer PS \& Murdoch FE 2000 Endogenously expressed estrogen receptor and coactivator AIB 1 interact in MCF-7 human breast cancer cells. PNAS 97 12536-12540.

Tora L, White JH, Brou C, Tasset DM, Webster NJG, Scheer E \& Chambon P 1989 The human estrogen receptor has two independent nonacidic transcriptional activation functions. Cell $\mathbf{5 9}$ 477-487.

Torchia J, Rose DW, Inostroza J, Kamei Y, Westin S, Glass CK \& Rosenfeld MG 1997 The transcriptional co-activator $\mathrm{p} / \mathrm{CIP}$ binds CBP and mediates nuclear-receptor function. Nature 387 677-684.

Tremblay A, Tremblay GB, Labrie F \& Giguère V 1999

Ligand-independent recruitment of SRC-1 to estrogen receptor $\beta$ through phosphorylation of activation function AF-1. Molecular Cell 3 513-519.

Tsai M-J \& O'Malley BW 1994 Molecular mechanisms of action of steroid/thyroid receptor superfamily members. Annual Review of Biochemistry 63 451-486.

Tzukerman MT, Esty A, Santiso-Mere D, Danielian P, Parker MG, Stein RB, Pike JW \& McDonnell DP 1994 Human estrogen receptor transactivational capacity is determined by both cellular and promoter context and mediated by two functionally distinct intramolecular regions. Molecular Endocrinology 8 21-30.

Verrier CS, Roodi N, Yee CJ, Bailey LR, Jensen RA, Bustin M \& Parl FF 1997 High-mobility group (HMG) protein HMG-1 and TATA-binding protein-associated factor TAF(II)30 affect estrogen receptor-mediated transcriptional activation. Molecular Endocrinology 11 1009-1019.

Voegel JJ, Heine MJS, Zechel C, Chambon P \& Gronemeyer H 1996 TIF2, a $160 \mathrm{kDa}$ transcriptional mediator for the liganddependent activation function AF-2 of nuclear receptors. EMBO fournal 15 3667-3675.

Voegel JJ, Heine MJ, Tini M, Vivat V, Chambon P \& Gronemeyer H 1998 The coactivator TIF2 contains three nuclear receptor-binding motifs and mediates transactivation through CBP binding-dependent and -independent pathways. EMBO Fournal 17 507-519.

Watanabe M, Yanagisawa J, Kitagawa H, Takeyama K-I, Ogawa S, Arao Y, Suzawa M, Kobayashi Y, Yano T, Yoshikawa H, Masuhiro Y \& Kato S 2001 A subfamily of RNA-binding DEADbox proteins acts as an estrogen receptor a coactivator through the N-terminal activation domain (AF-1) with an RNA coactivator, SRA. EMBO foumal 20 1341-1352.

Webb P, Lopez GN, Uht RM \& Kushner PJ 1995 Tamoxifen activation of the estrogen receptor/AP-1 pathway: potential origin for the cell-specific estrogen-like effects of antiestrogens. Molecular Endocrinology 9 443-456.

Xu Y, Klein-Hitpass L \& Bagchi MK 2000 E1A-mediated repression of progesterone receptor-dependent transactivation involves inhibition of the assembly of a multisubunit coactivation complex. Molecular and Cellular Biology 20 2138-2146.

Zhang CG, Krieg S \& Shapiro DJ 1999 HMG-1 stimulates estrogen response element binding by estrogen receptor from stably transfected HeLa cells. Molecular Endocrinology 13 632-643.

Received 2 October 2003 Accepted 20 October 2003 